\title{
Evaluation of Toxicity of Some Plant Materials Against the Bruchid (Callosobruchus maculatus (F.) (Coleoptera: Chrysomelidae) on Mung Bean (Vigna radiata (L.) Wilczek) Seeds in Storage
}

\section{Emeasor $\mathrm{KC}^{1 *}$ and Chukwu LA ${ }^{2}$}

${ }^{1}$ Department of Plant Health Management, College of Crop and Soil Sciences, Michael Okpara University of Agriculture, Umudike, Abia State, Nigeria

${ }^{2}$ Department of Agricultural Technology, Akanu Ibiam Federal Polytechnic, Unwana, Afikpo, Ebonyi State, Nigeria

*Corresponding Author: Emeasor KC, Department of Plant Health Management, College of Crop and Soil Sciences, Michael Okpara University of Agriculture, Umudike, Abia State, Nigeria.

Received: July 29, 2019; Published: August 29, 2019

DOI: 10.31080/ASAG.2019.03.0634

\section{Abstract}

A laboratory study was conducted in the laboratory of the Department of Plant Health Management of Michael Okpara University of Agriculture Umudike, to determine the toxicity of powders of Piper guineense fruits, Dennittia tripetala fruits Allium sativum bulbs, Zingiber officinale rhizomes against the cowpea seed bruchid Callosobruchus maculatus (F.) (Coleoptera : Chrysomelidae) on stored mung bean (Vigna radiata (L.)Wilczek) seeds. The experimental design was a 4 x 5 factorial fitted into Completely Randomized Design (CRD) with three replications. The rates for the different powders were $0.0,0.5,1.0,1.5,2.0 \mathrm{~g}$ admixed with $20 \mathrm{~g}$ of mung bean seeds placed in plastic containers. The effect of the treatments were assessed on insect mortality at 48 and 96 hours, oviposition 7 days post treatment, adult emergence on 28 days after infestation, and seed viability test at the expiration of the experiment (42 days post treatment). The results showed that plant powders were effective in controlling insect infestation by recording significantly higher mortality, reduction in the number of eggs laid, and suppression of the development and emergence of adult progenies from the treated mung bean seeds compared with the control. Piper guineense provided the best protection for stored mung bean at 2.0 g/20 g compared with the other treatments, followed by Allium sativum. Dennittia tripetala and Zingiber officinale were almost the same in their performance. Plant materials did not affect the viability of the seeds. The results obtained suggest that the plant materials possess insecticidal properties and can be utilized in protecting stored mung bean from $C$. maculatus infestation since they are environmental friendly, cheaper than synthetic insecticides and safer for humans.
\end{abstract}

Keywords: Mung Bean; Callosobruchus maculatus; Storage Insect Pests; Biopesticides; Toxicity

\section{Introduction}

Mung bean (Vigna radiata (L.) Wilczek) is one of the most important short season, summer growing legumes grown widely throughout the tropics and subtropics [1]. Mung bean cultivars [2] were a potential source of essential fatty acids, antioxidants, minerals and proteins. The seeds and sprouts are excellent examples of functional foods that lower the risk of various diseases [3]. The seeds and sprouts have health promoting effects in addition to their nutritive value [4]. Today there is an increasing interest in western countries in the sprouting of seeds as consumers demand minimally processed, additive-free, more natural, nutritional and healthy foods. The seeds may be milled or ground into flour for making noodles, breads and soups. In rural areas, the immature green pods are also used as vegetable. Mung bean stalks, leaves and husks constitute a significant proportion of livestock feed. Af- ter picking of the pods, the whole plant may be ploughed in the soil to improve fertility. Like other legumes, mung bean is attacked by field to stored insect pests. Insect pest can significantly reduce mung bean profitability, reducing both yield and seed quality.

In order to ensure food security for the citizenry, surplus grains are properly preserved in storage. Stored grains in addition to serving as a source of domestic food supply throughout the year, serve a as means to generate revenue for the farming families. Grains are however very susceptible to infestation by insect pests belonging to two main orders, Coleoptera (beetle) and Lepidoptera (moth), micro-organisms and to rodent pests in storage. Insects are the most important among storage pests because apart from their direct damage, they create conditions that allow secondary infection by rot organisms mainly fungi [5]. Once infection is established insect pests cause gradual and progressive damage leading to losses 
Evaluation of Toxicity of Some Plant Materials Against the Bruchid (Callosobruchus maculatus (F.) (Coleoptera: Chrysomelidae) on Mung Bean (Vigna radiata (L.) Wilczek) Seeds in Storage

212

in weight, nutritional, organoleptic and aesthetic quality of stored grains. The most important insect pest of mung bean during storage is the cowpea bruchid (Callosobruchus maculatus (F.)

Most efforts directed at protecting grains during storage in time past were concentrated on the use of synthetic insecticides. However, apart from their prohibitively high costs and non availability to the peasant farmers, they have other limitations including their residual effects on the stored grains, persistence, pest resistance and deleterious effects on non-target organisms [6]. These limitations necessitate the continuous search for new insecticides with novel mechanisms of action. In this regard, many scientist are screening natural products, particularly of edible plant species as sources of degradable insecticides safer to man and the environment, and more easily and cheaply produced as crude or partially purified extracts [7].

The objective of this work was to evaluate the effectiveness of powders of plant materials (Piper guineense fruits, Dennittia tripetala fruits, Allium sativum bulbs, Zingiber officinale rhizomes) in reducing the number of eggs and decreasing the development and emergence of adult progenies of bruchid beetle $C$. maculatus from the treated mung bean seeds.

\section{Materials and Methods}

\section{Insect culture}

The insects used to establish a laboratory colony of C.maculatus came from a batch of infested cowpea purchased at Umuahia main market, Abia State. Beetles were reared subsequently with fresh uninfested mung bean seeds in plastic containers covered with muslin cloth to allow air circulation and held tightly with rubber band. Insect rearing and the experiment were carried out at an ambient temperature of $28 \pm 2{ }^{\circ} \mathrm{C}$ and relative humidity of $75 \pm 5 \%$. One - two (1-2) day old adult bruchids were obtained by sifting the stock culture a day before the experiment.

Collection of uninfested mung bean grains and plant materials

Clean mung bean seeds were obtained from College of Crop and Soil Sciences, Michael Okpara University of Agriculture, Umudike, Abia State. The fruits, bulbs, and rhizomes of the plant materials were sourced from the Umuahia main market. These plant materials were evaluated for insecticidal activity against Callosobruchus maculatus.

The list of Plant materials used are given in Table 1.

\section{Preparation and application of plant materials}

The dried plant materials were seperately pulverized using a HP kitchen hammer mill (model KOAHLBACH). The powders were sieved particle size of $300 \mu \mathrm{m}$ with a British laboratory test standard sieve (serial number 133032) and kept in air tight plastic containers prior to use [8]. Each of the powders were weighed 0.5,1.0,

\begin{tabular}{|l|c|c|c|}
\hline Scientific name & Common name & Family & Part used \\
\hline Piper guineense & Guinea pepper & Piperaceae & Fruits \\
\hline $\begin{array}{l}\text { Dennettia } \\
\text { tripetala }\end{array}$ & Pepper fruit & Annonaceae & Fruits \\
\hline Allium sativum & Garlic & Liliaceae & Bulbs \\
\hline $\begin{array}{l}\text { Zingiber } \\
\text { officinale }\end{array}$ & Ginger & Zingiberaceae & Rhizomes \\
\hline
\end{tabular}

Table 1: List of plant materials used for the study.

1.5 and $2.0 \mathrm{~g}$ into plastic containers contianing $20 \mathrm{~g}$ of uninfected mung bean seeds and thoroughly mixed by manual agitation. A control experiment containing no plant power was also set up. Each treatment was replicated three times in a Completely Randomized Design (CRD).

Four freshly emerged adults of (1-2 day old) were introduced into the plastic containers and covered with muslin cloth held tightly by the perforated cover and rubber bands. Mortality counts of the bruchids were carried out at 48, and 96 hours by sieving out and counting all dead beetles in each container. Oviposition counts were done after 7 days by pouring out seeds in each container and counting the number of eggs laid. Adult emergence was recorded till 14 days after the first emergence. For viability test, 10 seeds were randomly selected from each container, moistened and put in petri dishes lined with filter paper and left for 7 days.

\section{Statistical analysis}

Data obtained were subjected to analysis of variance procedure and significant means were separated using Fishers' Protected Least Significant Difference at $5 \%$ level of probability.

\section{Results}

The mean percentage mortality of C.maculatus treated with powders of P.guineense fruits, D.tripetala fruits, A.sativum bulbs and Z.officinale rhizomes on stored mung bean seeds are shown on (Table 2) 48 hours after infestation. All the plant powders exhibited varying degrees of insecticidal activiteis killing $C$. maculatus more than the control $(\mathrm{P}<0.05)$. P. guineense caused the highest mortality of $20.0 \%$ followed by A. sativum with $15.0 \%$. The least mean percentage mortality was recorded by $D$. tripetala and $Z$. officinale with $13.30 \%$ respectively.

Percentage mortality of adult C. maculatus exposed to plant powder 96 hours after infestation is shown in (Table 3). $P$. guineense caused the highest mortality $56.70 \%$ followed by $A$. sativum $50.00 \%$, D. tripetala $45.00 \%$ and Z. officinale $43.30 \%$. The mortality effect of $P$. guineense was significantly $(\mathrm{P}<0.05)$ higher than $D$. tripetala and $Z$. officinale but significantly the same with A. sativum. The mean dosage effect on mortality of $C$. maculatus adults 96 hours after infestation shows that $2 \mathrm{~g} / 20 \mathrm{~g}$ mung bean seeds treatment had the highest mortality effect of $66.70 \%$. 
Evaluation of Toxicity of Some Plant Materials Against the Bruchid (Callosobruchus maculatus (F.) (Coleoptera: Chrysomelidae) on Mung Bean (Vigna radiata (L.) Wilczek) Seeds in Storage

\begin{tabular}{|l|c|c|c|c|c|c|}
\hline \multirow{2}{*}{$\begin{array}{c}\text { Treatment } \\
\text { (plant } \\
\text { extracts) }\end{array}$} & Dosages & \multicolumn{2}{|c|}{ g/20g mung bean seeds } & \\
\cline { 2 - 7 } & $\mathbf{0 . 0}$ & $\mathbf{0 . 5}$ & $\mathbf{1 . 0}$ & $\mathbf{1 . 5}$ & $\mathbf{2 . 0}$ & Mean \\
\hline $\begin{array}{l}\text { Piper } \\
\text { guineense }\end{array}$ & 0.00 & 25.00 & 25.00 & 25.00 & 25.00 & 20.00 \\
\hline $\begin{array}{l}\text { Dennettia } \\
\text { tripetala }\end{array}$ & 0.00 & 8.30 & 16.70 & 16.70 & 25.00 & 13.30 \\
\hline $\begin{array}{l}\text { Zingiber } \\
\text { pjacinale }\end{array}$ & 0.00 & 8.30 & 16.70 & 16.70 & 25.00 & 13.30 \\
\hline $\begin{array}{l}\text { Allium } \\
\text { sativum }\end{array}$ & 0.00 & 16.70 & 16.70 & 16.70 & 25.00 & 15.00 \\
\hline Mean & 0.00 & 14.60 & 18.80 & 18.80 & 25.00 & \\
\hline
\end{tabular}

LSD (0.05) Plant powders $=7.32(\mathrm{P}=0.225) \mathrm{ns}$

LSD (0.05) Dosages (Concentrations) $=8.19(<0.001)^{* *}$

LSD (0.05) Plant powders $x$ Dosages $=16.37(\mathrm{P}=0.966) \mathrm{ns}$

Table 2: Mean percentage mortality of adult C. maculatus exposed to selected plant powder 48 hours post treatment

\begin{tabular}{|l|c|c|c|c|c|c|}
\hline \multirow{2}{*}{$\begin{array}{c}\text { Treatment } \\
\text { (plant } \\
\text { extracts) }\end{array}$} & Dosages & \multicolumn{5}{|c|}{ g/20 g mung bean seeds } \\
\cline { 2 - 7 } $\begin{array}{l}\text { Piper } \\
\text { guineense }\end{array}$ & 0.00 & 58.30 & 66.70 & 75.00 & 83.30 & 56.70 \\
\hline $\begin{array}{l}\text { Dennettia } \\
\text { tripetala }\end{array}$ & 0.00 & 50.00 & 58.30 & 58.30 & 58.30 & 45.00 \\
\hline $\begin{array}{l}\text { Zingiber } \\
\text { officinale }\end{array}$ & 0.00 & 41.70 & 58.30 & 58.30 & 58.30 & 43.30 \\
\hline $\begin{array}{l}\text { Allium } \\
\text { sativum }\end{array}$ & 0.00 & 50.00 & 66.70 & 66.70 & 66.70 & 50.00 \\
\hline Mean & 0.00 & 50.00 & 62.59 & 64.60 & 66.70 & \\
\hline
\end{tabular}

LSD (0.05) Plant powders $=6.68 .32(\mathrm{P}=0.001)^{* *}$

$\operatorname{LSD}(0.05)$ Dosages (Concentrations) $=7.47(<0.001) * *$

LSD (0.05) Plant powders $x$ Dosages $=14.94(P=0.601) \mathrm{ns}$

Table 3: Mean percentage mortality of adult C. maculatus exposed to selected plant powder 96 hours post treatment.

The effect of treating mung bean seeds with plant powders on oviposition by C. maculatus is shown in (Table 4). There was reduction in oviposition in all the treated samples compared with the control. P. guineense had the best protectant action among the plant powders with mean oviposition count of 58.33\%, which was significantly different from other powders. Z. officinale had the least protectant action with the highest mean oviposition count of $66.80 \%$.

Adult emergence count of $C$. maculatus from mung bean seeds treated with plant powders is shown in (Table 5). Adult bruchid emergence was significantly suppressed by all the plant powders $(\mathrm{P}<0.05)$ when compared with the control. Piper guineense had the highest suppression effect, with mean count of 36.00 which was statistically different from other plant powders.

\begin{tabular}{|l|c|c|c|c|c|c|}
\hline $\begin{array}{c}\text { Treatment } \\
\text { (plant } \\
\text { extracts) }\end{array}$ & Dosages & \multicolumn{4}{|c|}{ g/20 g mung bean seeds } & \\
\hline & 0.0 & 0.5 & 1.0 & 1.5 & 2.0 & Mean \\
\hline $\begin{array}{l}\text { Piper } \\
\text { guineense }\end{array}$ & 88.33 & 64.00 & 57.67 & 47.00 & 41.67 & 58.33 \\
\hline $\begin{array}{l}\text { Dennettia } \\
\text { tripetala }\end{array}$ & 87.67 & 67.00 & 64.00 & 56.33 & 43.00 & 63.60 \\
\hline $\begin{array}{l}\text { Zingiber } \\
\text { officinale }\end{array}$ & 87.67 & 71.67 & 63.00 & 59.67 & 52.00 & 66.80 \\
\hline $\begin{array}{l}\text { Allium } \\
\text { sativum }\end{array}$ & 88.33 & 68.67 & 61.00 & 52.67 & 45.00 & 63.13 \\
\hline Mean & 88.00 & 67.83 & 59.92 & 53.92 & 45.42 & \\
\hline
\end{tabular}

LSD (0.05) Plant powders $=3.82(\mathrm{P}=0.001)^{* *}$

LSD (0.05) Dosages (Concentrations) $=4.21(<0.001) * *$ LSD (0.05) Plant powders $x$ Dosages $=8.54(\mathrm{P}=0.485) \mathrm{ns}$

Table 4: The effect of treating mung bean seeds with selected plant powders on oviposition by $C$. maculatus.

\begin{tabular}{|c|c|c|c|c|c|c|}
\hline \multirow{2}{*}{$\begin{array}{l}\text { Treatment } \\
\text { (plant } \\
\text { extracts) }\end{array}$} & \multirow{2}{*}{$\begin{array}{c}\text { Dosages } \\
0.0\end{array}$} & \multicolumn{4}{|c|}{$\mathrm{g} / 20 \mathrm{~g}$ mung bean seeds } & \multirow[b]{2}{*}{ Mean } \\
\hline & & 0.5 & 1.0 & 1.5 & 2.0 & \\
\hline $\begin{array}{l}\text { Piper } \\
\text { guineense }\end{array}$ & 73.33 & 43.33 & 30.67 & 20.00 & 12.67 & 36.00 \\
\hline $\begin{array}{l}\text { Dennettia } \\
\text { tripetala }\end{array}$ & 73.33 & 51.33 & 41.00 & 30.00 & 20.00 & 43.13 \\
\hline $\begin{array}{l}\text { Zingiber } \\
\text { officinale }\end{array}$ & 71.33 & 50.67 & 41.00 & 33.67 & 26.33 & 44.60 \\
\hline $\begin{array}{l}\text { Allium } \\
\text { sativum }\end{array}$ & 76.00 & 49.00 & 39.00 & 29.33 & 21.00 & 42.87 \\
\hline Mean & 73.50 & 48.58 & 37.92 & 28.25 & 20.00 & \\
\hline
\end{tabular}

LSD (0.05) Plant powders $=3.32(\mathrm{P}=0.001)^{* *}$

LSD $(0.05)$ Dosages (Concentrations) $=3.71(\mathrm{P}<0.001) * *$ LSD (0.05) Plant powders $x$ Dosages $=7.43(\mathrm{P}=0.307) \mathrm{ns}$

Table 5: Adult Emergence count of C. maculatus from mung bean seeds treated with selected plant powders.

The mean percentage germination of mung bean seeds treated with plant powders is shown in (Table 6). There was no significant difference among the plant powders on percentage germination of mung bean seeds treated. The dosage $0.5 \mathrm{~g} / 20 \mathrm{~g}$ mung bean seeds had the least percentage germination with $30.00 \%$ which differed from others.

\section{Discussion}

The study shows that the powder extracts had insecticidal activity against $C$. maculatus and can be used for the control of the bruchid on mungbean storage. They conformed with the properties required for controlling insects feeding on internal plant parts 


\begin{tabular}{|c|c|c|c|c|c|c|}
\hline \multirow{2}{*}{$\begin{array}{c}\text { Treatment } \\
\text { (plant } \\
\text { extracts) }\end{array}$} & \multirow{2}{*}{$\begin{array}{c}\text { Dosages } \\
0.0\end{array}$} & \multicolumn{4}{|c|}{$\mathrm{g} / 20 \mathrm{~g}$ mung bean seeds } & \multirow[b]{2}{*}{ Mean } \\
\hline & & 0.5 & 1.0 & 1.5 & 2.0 & \\
\hline $\begin{array}{l}\text { Piper } \\
\text { guineense }\end{array}$ & 23.33 & 26.67 & 36.67 & 50.00 & 63.33 & 40.00 \\
\hline $\begin{array}{l}\text { Dennettia } \\
\text { tripetala }\end{array}$ & 23.33 & 30.00 & 46.67 & 46.67 & 56.67 & 40.67 \\
\hline $\begin{array}{l}\text { Zingiber } \\
\text { officinale }\end{array}$ & 20.00 & 33.33 & 46.67 & 46.67 & 53.33 & 40.67 \\
\hline $\begin{array}{l}\text { Allium } \\
\text { sativum }\end{array}$ & 23.33 & 30.00 & 40.00 & 50.00 & 60.00 & 40.67 \\
\hline Mean & & 22.50 & 30.00 & 42.50 & 48.33 & 58.33 \\
\hline
\end{tabular}

LSD (0.05) Plant powders $=3.40(\mathrm{P}=0.957) \mathrm{ns}$

$\operatorname{LSD}(0.05)$ Dosages (Concentrations) $=3.80(<0.001)^{* *}$

LSD (0.05) Plant powders $x$ Dosages $=7.60(\mathrm{P}=0.051)^{*}$

Table 6: Percentage Germination of mung bean seeds treated with selected plant powders.

which include; toxicity to adults, reduction of oviposition, toxicity to immature stages prior to or immediately following penetration of plant tissues [9]. Toxicity on mortality started manifesting 48 hours and progressed to 96 hours after infestation. At 96 hours, mortality progressively expressed above $70 \%$. P. quineense significantly differ from other powder extracts.The results showed that the plant powders were effective in reducing insect infestation by recording significantly higher mortality when compared with the control. P. guineense fruit provided the best protection for stored mung bean by exhibiting an increased mortality $56.70 \%$ compared with the other treatments at 96 hours after infestation. A.sativum bulb powder ranked second with $50.00 \%$ mortality. The result obtained revealed that there was no significant difference in the percentage mortality of D.tripetala fruits and Z.officinale rhizomes powder. Similarly the results agree with the report of [10] on the toxicity of various plant materials on C.maculatus. The powder extracts deterred oviposition to $C$. maculatus which may have been as a result of the active ingredient in the plant materials. The result was in line with Emeasor., et al. [11].

According to researchers, ovipositional preference has been attributed to seed coat morphology and seed size [12]. Evidently, more eggs were laid on seeds that are large, whole, smooth and pristine. There was a significant reduction as dosage increases. The result was in line with [13]. The powder extracts suppressed the adult emergence of the bruchids. It has also been suggested that powder extracts could cause the death of insect pest by the particles blocking the spiracles of the bruchids thereby impairing respiration and causing asphyxiation and death. The suppression of the beetles were dosage dependent. Higher dosages suppressed adult emergence more. The viability of the mung bean seeds were not affected by the plant material powders. There were no significant difference among the plant powders. Seeds not attacked by the beetle germinated normally.

\section{Conclusion}

The results showed the insecticidal potentials of the plant materials in protecting stored mung bean seeds from damage by $C$. maculatus without any deleterious effects on viability of seeds. All the plant materials showed varing degrees of insecticidal abilities although Piper guineense performed best among the plant materials used. We therefore recommend the use of these plant materials especially P. guineense in the control of Callosobruchus maculatus in storage as against synthetic insecticides, since it is cheaper, safe, easy to apply, and ecologically friendly.

\section{Bibliography}

1. Thomas R M J., et al. "The effect of timing and severity of water deficit on growth, development, yield accumulation and nirogen fixation of mungbean". Field Crops Research 86.1 (2004): 67-80.

2. Anwar F., et al. "Chemical composition and antioxidant activity of seeds of different cultivars of mung bean". Journal of food science 72.7 (2007): S503-S510.

3. Pasko P., et al. "Analysis of the selected phenolic acids and flavonoids in Amaranthus cruentus and Chenopodium quinoa seeds and sprouts by HPLC method". Acta Chromatographica 20.4 (2008): 661-672.

4. Liu B., et al. "Nutritional evaluation and antioxidant activity of sesame sprouts". Food Chemistry 129.3 (2011): 799-803.

5. Oke O A and Muniru S. "Fungi associated with stored rice grains and their implications". Journal of Research and Review in Science 2 (2001): 6-9.

6. Elhag E A. "Deterrent effects of some botanical products on oviposition of the cowpea bruchid Callosobruchus maculatus (F.) (Coleoptera : Chrysomelidae)". International Journal of Pest Management 46.2 (2000): 109-113.

7. Rahman A and Talukder F A. "Bioefficacy of some plant derivatives that protect grain against the pulse beetle Callosobruchus maculatus". Journal of Insect Science 6.3 (2006): 1 -10.

8. Okonkwo E U and Okoye W I. "The efficacy of four seed powders and the essential oils as protectants of cowpea and maize grains against infestation by Callosobruchus maculatus (F.) (Coleoptera ; Bruchidae) and Sitophilus zeamais (Motschulsky) (Coleoptera: Curculionidae) in Nigeria". International Journal of Pest Management 42.3 (1996): 143-146.

9. Ogunwolu E O and Odunlami A T. "Suppression of seed bruchid Callosobruchus maculatus (F.) Development and damage on cowpea Vigna unquiculata (L.) Walp with Zanthoxylum zanthoxyloides (Lam) Watern. (Rutaceae) root bark powder Crop Protection 15 (1996): 603-607. 
10. Oparaeke A M., et al. "Evaluation of seed and leaf powder of neem (Azadirachta indica A. Juss) and Pirimiphos methyl for control of Callosobruchus maculatus (F) in stored cowpea". Entomological Society of Nigeria. 31 (1998): 237-242.

11. Emeasor K C., et al. "Toxicological assessment of some Nigerian seed powders against the maize weevil, Sitophilus zeamais". African journal of Applied Zoology and Environmental Biology 4 (2002): 83-86.

12. Messina F J and Renwick J A A. "Effectiveness of oils in protecting stored cowpea from the cowpea beetle (Coleoptera : Bruchidae)". Journal of Economic Entomology 76.3 (1983): 634-636.

13. Emeasor K C., et al. "Insecticidal activity of some seed powders against Callosobruchus maculatus (F.) (Coleoptera : Bruchidae) on stored cowpea". Journal of Plant Diseases and Protection 112.1 (2005): 80-87.

\section{Volume 3 Issue 9 September 2019}

(C) All rights are reserved by Emeasor KC and Chukwu LA. 